\title{
6. The Structural Violence of Resource Extraction in the Purari Delta
}

JOSHUA A. BELL

The Papuan forests teem with valuable timbers, choice gums, medicinal herbs, aromatic spices, and a hundred products which, to win, need only the educated efforts of the aboriginals, for the enrichment of the world's markets (Bevan 1890: 284).

\section{Introduction}

On the bank of the upper reaches of the Aivei River sat an empty cargo container, detritus from a failed logging and oil palm venture initiated in 1993 (Filer with Sekhran 1998: 188-9; Bell 2009). In 2002, when I first encountered this container, the forest was slowly engulfing its blistering orange-red surface (Figure 6.1). All the heavy equipment brought to this site had been removed or scavenged for parts, and the empty cargo container was all that remained. In 2010, when I returned, the container had slipped from the bank and was now submerged in the river. While every forest has its share of the remnants of failed projects, the forests, mudflats and tidal creeks of the Purari Delta, and the wider Gulf of Papua, have more than their fair share. Their presence and lingering absence serve as a testament to the failed and ongoing intersection this region and its inhabitants have with capitalism, and the extent to which forests are central to these engagements. ${ }^{1}$

1 See Mawyer, Chapter 2, this volume, as well as the evocative explorations by Raffles (2002), Kosek (2006) and Gordillo (2011). 


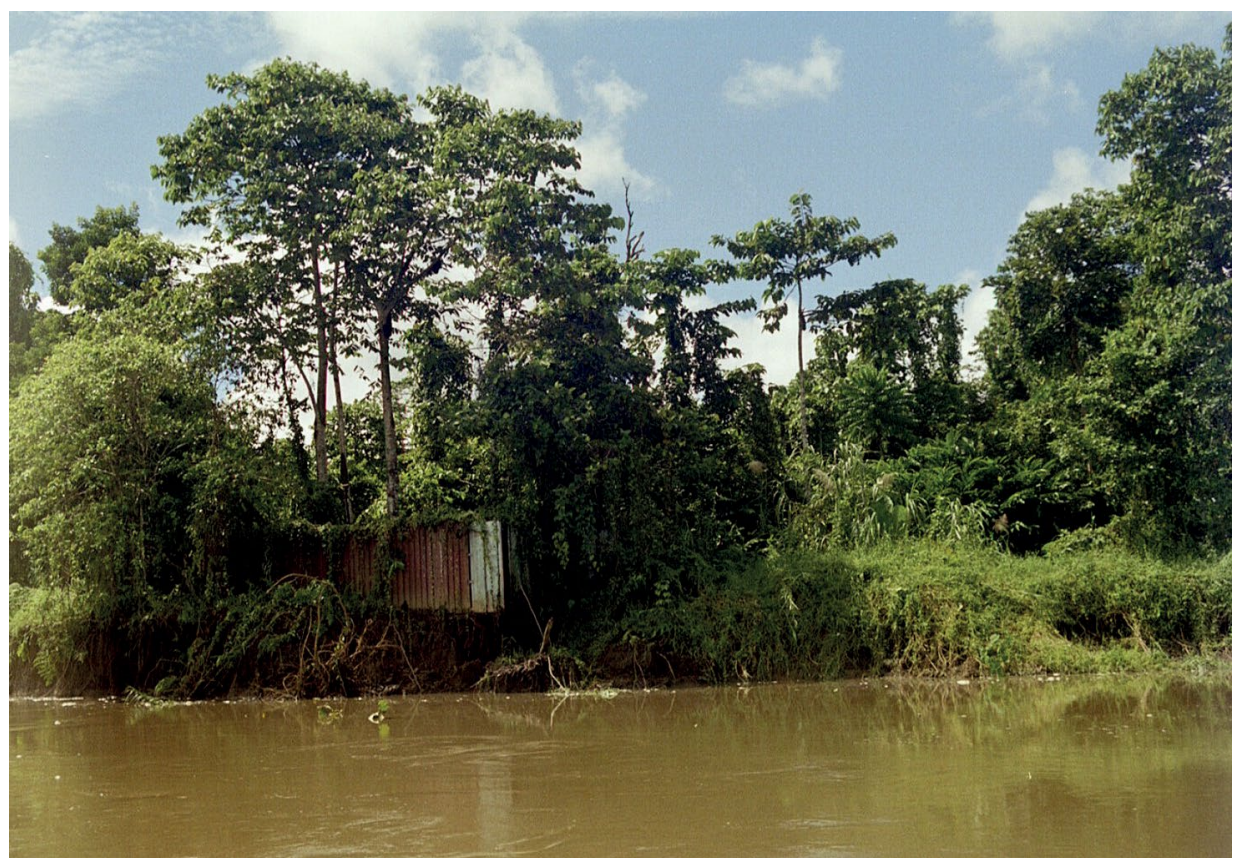

Figure 6.1 Empty container enveloped by the forest on the banks of the Aivei distributary of the Purari River.

Source: Photo by Joshua A. Bell, 2002.

This container possesses companions to the west on the bank of the Pie River at Baimuru government station. One has sat next to the police station for at least 20 years, and until 2010 was used as the holding cell (Figure 6.2). This is where, following verbal rebukes and typically a beating by the police, the accused were kept for a night to several days before being freed. More often than not, the occupants of this cell were young men charged with the cultivation and possession of kuku dipi (marijuana), the making of 'steam' (home-made alcohol) and having an illegal home-made gun. Since 'zoom' (outboard motor fuel) is too scarce or costly to be used for transporting prisoners to the provincial capital (Kerema) or the national capital (Port Moresby), these young men would either return to their village or remain hanging out in Baimuru, becoming a lingering source of anxiety for all. Collectively, these young men, and the lawlessness they are perceived to embody, are understood to be emblematic of the new era of consumption, jealousy and the ascendancy of individualism over kin relations, known locally as moni kaeou ('money ground') (Bell 2006a). ${ }^{2}$

2 Indicative of this new order, the first murder occurred at Baimuru station in December 2005 around Christmas. The victim, a man in his late 40 s, is said to have been killed while walking home in the early morning by young men he angered at an all-night card game (Kaia Rove, personal communication, 6 April 2006). Gambling has become a new norm in the delta as communities become temporarily awash with money through royalty payments (Bell 2009). 


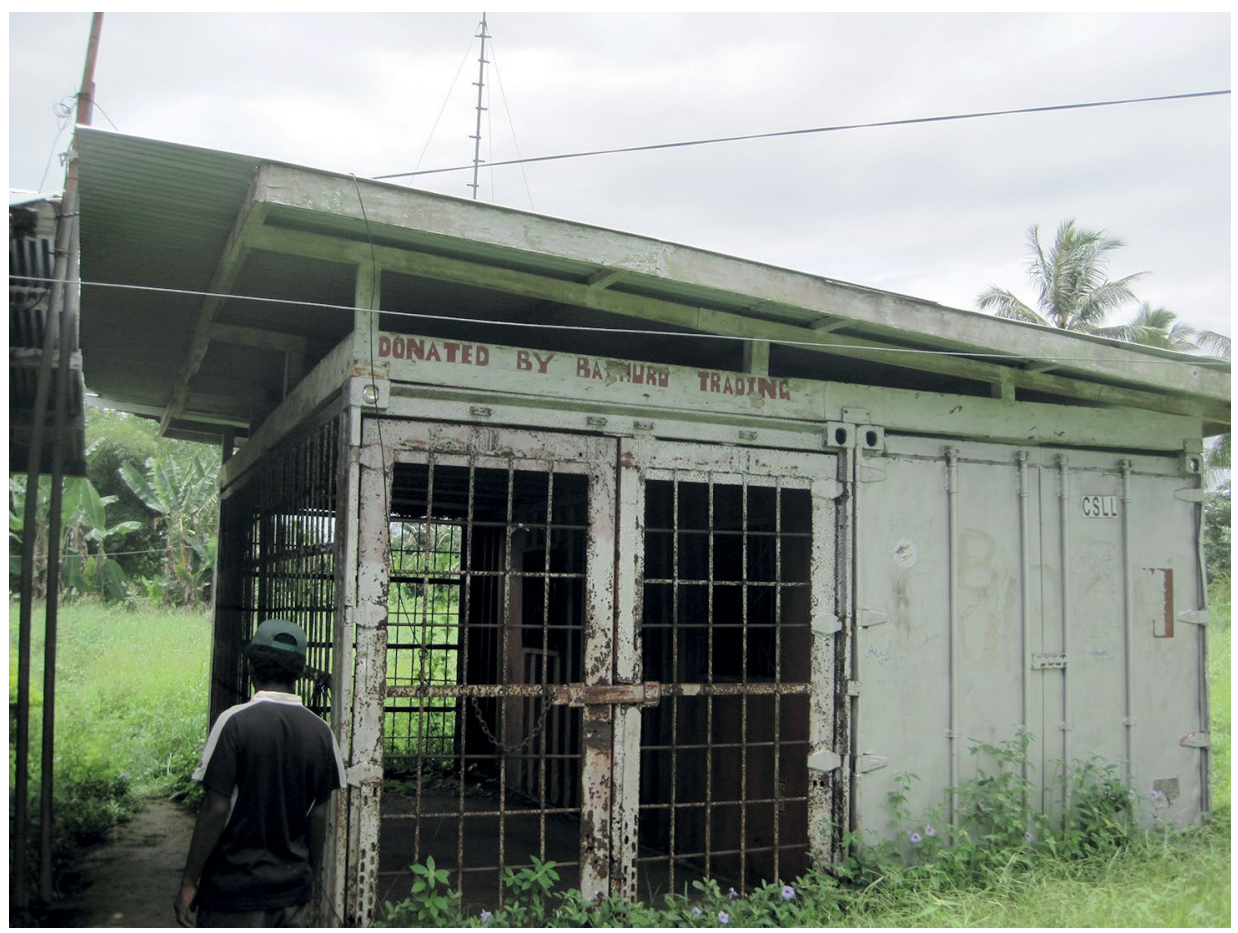

Figure 6.2 Container turned into a jail, now disused.

Source: Photo by Joshua A. Bell, 2010.

Further south on the river's bank lie another set of containers that have been converted into the base for a watchtower from which locally hired security guards sit waiting for both real and imagined threats (Figure 6.3). The watchtower helps guard the operations of ethnic Chinese merchants affiliated with the Malaysian multinational Rimbunan Hijau, which has conducted the bulk of the logging operations in the Papuan Gulf. These merchants came to the delta on the invitation of the current parliamentary member for the Kikori Open seat, who owns the plot of land on which the watchtower has been built. Their operations are part of the larger eclipsing of locally owned and operated businesses. The success of this operation has made it and the ethnic Chinese operators the objects of much jealousy. The intensity of this jealously emerged most starkly in 2005 when 'rascals' (raskols) came by outboard motor from Kerema, robbed the store, and almost killed its manager, Jackson. When I met him in 2006, Jackson gladly showed me the scar that radiates down from his shoulder along his back where a bush knife split him open. Following the elaboration of this encounter in Tok Pisin, he quickly changed the conversation to ask whether I had any United States currency to exchange with him for Papua New Guinea (PNG) kina. 


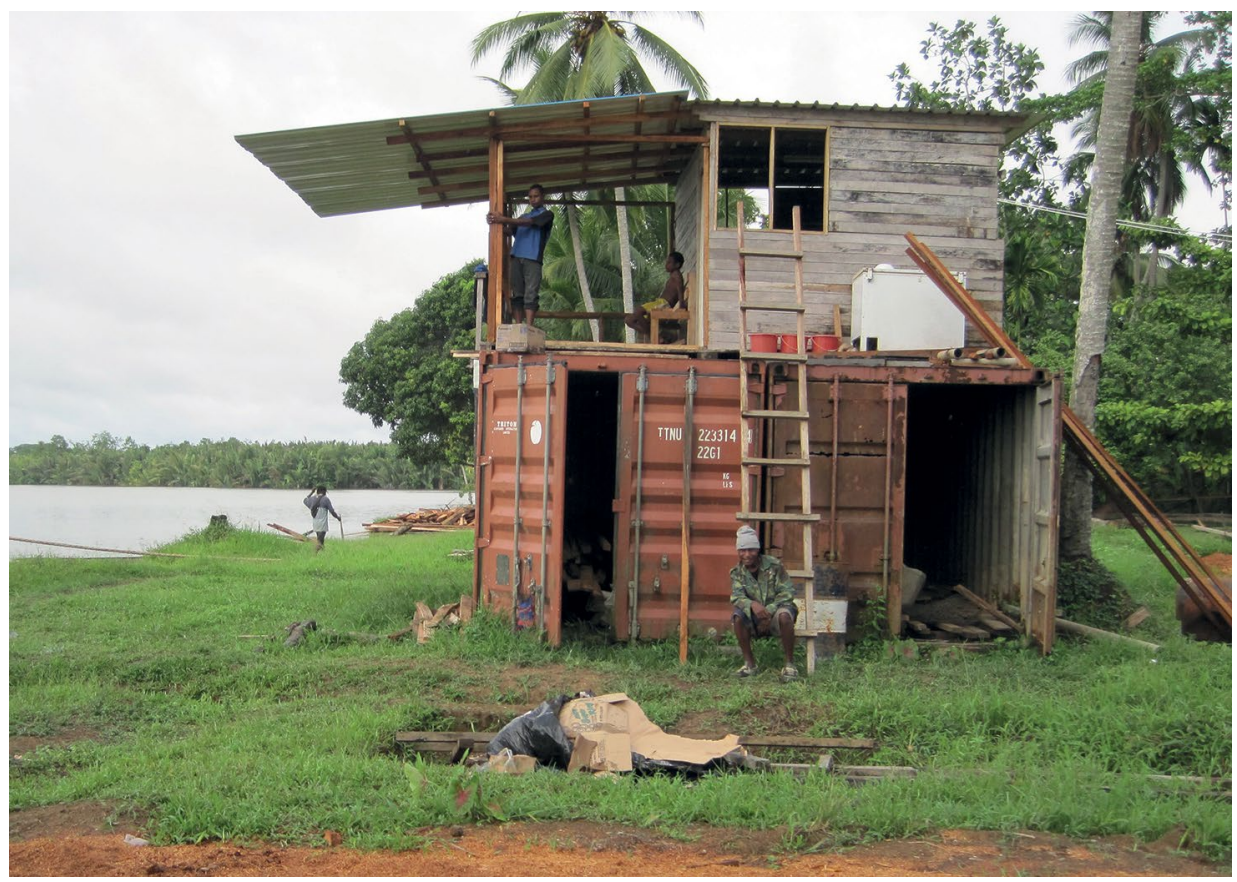

Figure 6.3 Containers on the bank of the Pie River used to form a security tower outside a Chinese-run trade store in Baimuru.

Source: Photo by Joshua A. Bell, 2010.

Condensed in this detritus of failed and ongoing resource extraction, and the ongoing wakes that these encounters help generate, we have vestiges of Tsing's (2005) 'frictions', where the assemblage of local, global, human, non-human, nature and culture are materialised and reconfigured (Raffles 2002). These and other containers in the delta are 'good to think' not only because of the different scale-making projects they help enact and foreground (Tsing 2005: 57), but also due to the metaphorical and relational aspects of 'cargo' (kago) by which Melanesians remake the terms of their engagement with the economic and moral inequities of the global economy of resource extraction (Wagner 1981). If the first container evokes failure and the lurking quality of things submerged, then the second and third are evocative of the misunderstandings, violence and transactions, legal and illegal, that occur as these projects unfold. All conjure up the entropic effects of the delta and the ongoing attempt by outsiders to wrest resources - whether they be coal, oil, timber, sago, copra, rubber or eaglewood - from its enduring flow. These activities have directly and indirectly involved inhabitants of the delta in the reworking of place and subjectivity, and are part of the cutting and reknitting of the networks by which the delta as both real and imagined place is connected and disconnected. 
Building on my earlier work on the informal economies around resource extraction and the transformative effects of incorporated land groups (Bell 2006b, 2009), I focus here on the conjoined effects and ruptures of resource extraction and the various types of violence they engender. Specifically, I draw on Farmer's articulation of 'structural violence' (Farmer 2004), through which he attempts to understand the conditions and effects of inequality in and on communities. A key aspect of this violence is the erasure of history and understanding of the relations that engender this oppression. ${ }^{3}$ Formulated in response to the particular conditions of Haiti, structural violence can be seen to be part and parcel of what Harvey (2005), reformulating Marx, refers to as 'accumulation by dispossession'. This inequality - whether economic, social or representational — is an increasingly salient aspect of neoliberalism and capitalism more generally, and has profound effects along the supply chain, which in turn feed back and impact local communities. Structural violence is particularly visible in the frontiers of capitalism where resources are made and unmade, and relations and histories erased (Tsing 2005; Kosek 2006). As we shall see, structural violence and its effects are a key force in the shaping of people's understandings of the assemblage of relations that are critical to the formation of their environmentality (Agrawal 2005: 166). I am specifically interested in how the various forms of violence have shaped I'ai people's responses to outside efforts to tap their forests for the world's markets, and the corresponding transformations of their knowledge about the forest, others and the self that these engagements have involved. In this way, I seek to contribute to discussions of how the state and companies articulate their relations with communities through violence (Dinnen and Ley 2000; Wood 2006; Lattas 2011), with the full acknowledgement of how difficult writing about such violence is, and the dangers in both overstating and understating its slippery dimensions (Scheper-Hughes and Bourgois 2004).

Moving through a brief history of resource extraction in the Purari Delta, I proceed to a discussion of the wakes of recent events, memories and current processes. In what follows, I do not make an attempt to provide a comprehensive history of Purari communities' engagement with resource extraction; rather, I offer some salient events that show how relationships have been transformed over time.

\footnotetext{
3 Farmer's formulation builds explicitly on the work of the Latin American theologian Johan Galtung (1969), and has clear parallels to the articulations of 'everyday violence' (Scheper-Hughes and Bourgois 2004) and 'symbolic violence' (Bourdieu 1991), which are equally concerned with the power dynamics of lived reality and the misrecognition of the causes of inequality.
} 


\section{Histories of Resource Extraction in the Purari Delta}

While my focus is primarily on events since 2000, it is important to situate these contemporary processes within longer-term and fractured histories of resource extraction in the region. These intersecting histories are products of what Theodore Bevan (1890) termed 'the enrichment of markets'. Credited with being the first European to discover and travel up the Purari River, Bevan's remarks in this chapter's epigraph are prescient of the later ventures that came to the region. His optimism resonates with these projects and foregrounds the ways in which the Purari Delta and its surroundings have been reconfigured as resources through a variety of ventures: the Vailala oil fields (1912), Wame sawmill (1922), surveys by the Australasian Petroleum and Anglo-Persian companies (1920s-1930s; 1950s-1960s), the proposed Wabo dam (1970s), Rimbunan Hijau's logging ventures (since 1995), InterOil's prospecting and drilling (since 2002), and resurgent interest in the Purari hydropower project (2010). Moreover, Bevan's relentless collecting of flora, fauna and ethnographic specimens is emblematic of the bundling of activities carried out by most Europeans in the region, whereby various entities became resources to be extracted and sold or collected for science (Welsch et al. 2006; Bell 2013).

While far from uniform, these resource extraction projects over the past 100 years have worked to transform communities' relationships to their forests as the colonial and post-colonial state has sought to gain access to the region and extract timber. To extend a metaphor drawn from the reality of the delta's environment, this process continually involves ebbs and flows, and periodic submerging and revelation of what has been covered. As a result, this process is uneven at best, and is re-articulated anew with each generation and each new project regionally.

Following Bevan's initial incursion into the Purari Delta, the region slowly came under European influence. In 1905, Reverend John Henry Holmes of the London Missionary Society inhabited Urika station on the delta's coast (LMS 1906: 318). Alongside his evangelising, Holmes also sought to transform communities through work. He began employing Purari boys to manufacture rattan chairs, which they sold within Papua and in Australia. Until the 1940s, kaia ini, as the rattan was known, was also used in the construction of the central ritual figure, the kaiaimunu. The construction of these wicker figures was central to the empowerment of male initiates (Williams 1923a; Bell 2010). While it is unclear if Holmes understood the symbolic associations of kaia ini, these industrial activities were central to the belief of Holmes and other London 
Missionary Society members that spiritual salvation could be achieved through hard work. The symbolic analogies at play here most likely did not escape Purari people's attention.

Alongside these uses of forest materials, Holmes also embarked on modification of Urika's immediate landscape. Holmes quickly encountered the nesting of relationships that Purari communities have to place. As Holmes remarks, upon settling in Urika, '[we] unwittingly ... had stepped into a totemic hornet nest; we were stung on every hand, but were innocent of the provocation' (Holmes 1924: 145). He comments:

We had to fell trees, cut canals and demolish on one hand that we might build up on the other. Our proceedings alarmed people in all the villages; they were concerned because the island, being an awapa-mako [opa mako, place of spiritbeings], their totem-kinship demanded of them approval or disapproval, of our doings. (Holmes 1924: 145-6)

Holmes's comments are suggestive of the conflicts that arose around cosmologically important places for the Purari people during this early period, as well as their perceptions of subsequent transformations enacted by later projects.

Far from being an undifferentiated tidal swamp, the delta was and still is understood to be a palimpsest of culturally significant places whose meanings are constituted through both past and present practices and contemporary narrative. Airu omoro, a class of narratives, speak of these connections understood as kapea (paths) by which past actions of imunu (ancestral spirit-beings) are inscribed in the landscape connecting people to their wider world (Bell 2006b). Prior to the iconoclasm of the Tom Kabu Movement (1946-69), communities materialised their relations to imunu through large-scale rituals and displays of objects, which acted as the ruru ('skins') of these otherwise immaterial beings (Williams 1924; Maher 1961; Bell 2010). Accompanied by feasting, these rituals helped affirm traditional leadership positions and relations within descent groups. The ravi (longhouses) that housed this material were quite literally forests of relations transposing, through carved images and masks, ancestral presence with various sensorial and social effects. With the abandonment of the ravi and with few heirloom objects left (Bell 2009), the remaining imunu are understood to reside in specific trees, whirlpools and stones and become visible through taking on different human, animal or mechanical forms. ${ }^{5}$ Consumption habits

4 In 1913 Holmes gives a sense of the scope of these endeavours: 'Side by side with building our station, canal-making, land-clearing for gardens to support a family ranging from 150 to 300 during the 5 yrs a coconut plantation of 6000 young palms was planted and in another year the first fruits from this plantation will be gathered' (CWM/LMS 1913).

5 There are three types of imunu: kae ('earth') imunu, ere ('water') imunu and iri ('tree') imunu. I was told that iri imunu are the most like humans. 
and subsistence activities, as elsewhere in Melanesia, further root people into this system whereby the growth of one's children's bodies is understood to be a manifestation of ancestral efficacy and parental nurture. Christianity (Seventhday Adventist, Pentecostal and United Church denominations) has helped to further attenuate communities' engagement with, and understanding of, these beings. For many, the forest has become a place of danger where demonic forces now dwell (Brunois 1999). These beings pioneered the kapea that form the present landscape that underlie social formations and their histories, all of which have become central to the Purari people's negotiations about resource ownership (Bell 2009).

Within a year of the establishment of Urika, the administration created a government station at Kerema from which it could launch semi-regular patrols into the delta (Murray 1912: 177). When the area was deemed pacified after 1908, the administration sponsored several expeditions to follow on initial discoveries of coal and oil in the Papuan Gulf (Carne 1913; Wade 1914; see also Rickwood 1992: 38-42). These surveys resulted in the identification of the Vailala oilfields in the neighbouring Gulf Division in 1912. This site, along with Papua's nascent plantation economy, needed new sources of labour, so recruiters turned to the delta. ${ }^{6}$ Labour increasingly involved men in unprecedented travel out of the delta to plantations in the neighbouring Gulf and Central districts, as well as to work in Port Moresby. During these sojourns, men were exposed to Papuans of various cultural backgrounds, the Australian work regime, and the evolving colonial language of Police Motu. While the London Missionary Society mission condemned labour recruitment because of its effects on their own missionisation efforts (LMS 1915: 328), the colonial administration felt that labour was beneficial (Murray 1912). This domestication of Purari communities through labour, laws and missionisation was part of the broader attempt to domesticate communities and harness their resources.

Purari communities were not passive participants within the emerging colonial economy, but engaged in a series of tacit and explicit negotiations about the nature and extent of their participation. The so-called 'Vailala Madness' of 1919 dramatically brought the simmering regional disenchantment with the colonial economy, and the inequality of the moral relationships it engendered, into sharper focus. The explosion of economic activity and the new valuations of regional resources helped contribute to this event (Williams 1923b; Bell 2006b). While temporarily affecting communities on the coast, the effects of the Vailala

6 The 1907 Native Labour Ordinance allowed individuals to be indentured for up to three years. All contracts were signed in the presence of the district's resident magistrate or assistant resident magistrate. The resident magistrate received the labourers' wages monthly and then witnessed their being paid in full upon the end of the contract. In the event of a labourer's death, he would pay out the wages to relatives in the village (Lewis 1996: 49). 
Madness soon passed, as new colonial policies, namely the Native Taxes Ordinance (1919) and the Native Plantations Ordinance (1920), prompted communities to participate more fully in the commercial transactions. ${ }^{7}$

During this decade several new regional commercial ventures gave Purari communities more direct access to trade goods and became local sources of employment (Territory of Papua 1923: 53; Hope 1979). The most successful and long-lasting commercial venture established was the Wame sawmill and trade store. Established in 1922 by Lewis Lett, a successful trader and planter in Gulf Division, Wame quickly became an economic and social hub for the district (Woodward 1922: 1). The sawmill processed timber until 1958, after which it was moved to the newly established station of Baimuru in 1961. ${ }^{8}$ By 1925 the sawmill employed 65 villagers from all over Delta District and was home to three Europeans (Liston-Blyth 1925: 2). By 1943 the sawmill employed 350 labourers (Ross 1943: 4) and was sending timber to Daru and Port Moresby (Chance 1937: 2). While trees were already sites of valuation that were 'generative or productive relations between persons' (Leach 2004: 42), the sawmill's activities helped trees become a new locus by which to create and sustain relationships with Europeans, and indeed within Purari communities themselves. For example, on 22 August 1926, the assistant resident magistrate, C.H. Karius, records that 75 landowners from the Baroi villages of Akiaravi, Oravi and Evara were paid $£ 90$ (or just over $£ 1$ each) in return for the right to cut timber along the banks of the Baroi River over a period of 10 years (Karius 1937: 2-3). These funds entered into the local economy in the form of trade goods. Such commercial opportunities augmented those carried out around sago, and allowed for the furthering of asymmetric power relations between elders, who held hereditary chieftaincies, and the young men who struggled to obtain trade goods through their labour. While colonial threats of violence often forced men into these labour situations, as much as their wanderlust, on their return they faced sorcery reprisals within

$7 \quad$ Taxes were imposed on all males between 18 and 36 and placed in a special fund used only for projects that were deemed beneficial to the Papuan, such as the funding of schools, hospitals and technical training (Lewis 1996: 149). The Native Plantations Ordinance set aside land near villages for plantations, and the government provided tools and seeds, while the villages supplied their labour. The resulting profits were used to pay their annual tax, and helped instil villagers with a sense of industry. In the early 1920s coconut plantations were established near every major village in the delta, and villagers were encouraged to try planting a range of produce (Territory of Papua 1923: 50). While it is difficult to trace the impacts of these policies, they not only induced men to more readily sell their labour, but most likely also induced them to sell their resources of timber, sago and fish.

8 In 1937 Steamships Trading Company purchased a half interest in the operation. During World War II the mill was taken over by the Australian military administration for timber production for the war effort, although production slowed due to the lack of boats to transport milled timber to Port Moresby (Bennett 2009: 103). After the war, the operator was Port Romilly Timber Mills (Nicklason 1969: 243-48). 
their community if they proved unwilling to distribute their goods. ${ }^{9}$ This form of social disruption, one of the tacit results of resource projects escalating the uneven distribution of wealth, is ongoing in the delta, and remains one of the most destabilising effects of these projects (Bell 2006a).

This structural violence was accentuated by the venereal diseases that these capitalist incursions helped to spread. Although present in 1912, the increased rate of infection in 1922 was such that the administration established a medical outpost near the mouth of the Aivei River (Territory of Papua 1923: 116). The increased transmission in the delta was deemed a result of the traffic of women from the Urama and Goaribari communities for trade goods and shell valuables (Woodward 1921: 1), but no mention is made of European involvement. As with the present circumstances of the Papuan Gulf, logging and oil exploration camps created new commodity contexts in which prostitution flourished as communities without direct access to European goods attempted to access them. As recalled by I'ai elders in 2001 and 2002, Goaribari groups continued to come to Purari villages until 1947, and to the camps into the 1960s. The structural inequalities that helped give rise to the trade of sexual services for trade goods has continued into the present. Since 2000, it has not been uncommon for communities seeking to access the flow of real and imagined wealth around present-day resource extraction projects to seek to marry their daughters to men working in the camps and to obtain materials from the logging ships (Bell 2006a; Hammar 2010).

Following World War II, the region was transformed by the Tom Kabu Movement, which combined iconoclastic fervour with intense interest in economic independence through cash cropping (Maher 1961, 1984). Although suppressed by the Australian administration, this movement helped to open up communities to the possibilities of new things, and shift the cultural expectations and horizons of communities. Soon afterwards, the Australasian Petroleum Company (APC) began conducting surveys in the delta's hinterland and to the west in Kikori (Hicks 1953: 695-700; Pym 1958). In the 1950s, the APC established a base at Middletown, at the juncture of the Sirebi and Kikori rivers, and by 1955 had four rigs operating. It spent $£ 3$ million a year and had a labour force of 'thousands' of men through Delta District and beyond, with 20 vessels, numerous launches, helicopters and so forth (Hope 1979: 249). Following these unsuccessful surveys, in 1960, the Consolidated Zinc Corporation and the British Aluminium Company began investigating the

9 During a patrol in 1914, the resident magistrate of Delta Division reported that, in the village of Pai-ara, 'young boys that go to work, on their return are obliged to hand over some of their hard earned trade, to appease the old scoundrels who profess to be Sorcerers ... their dread of the Sorcerer is so great, that some of the boys as soon as they arrive, go to the Sorcerer, and give him some of their trade without being asked for it by the Sorcerer, this is done to ensure that the Sorcerer will leave them alone' (Ryan 1914: 5-6). 
upper Purari to initiate a hydroelectric scheme. In 1972 the Japanese company Nippon Koei conducted another preliminary study of the feasibility of a dam, which in 1973 was reviewed by the Australian company Snowy Mountains Engineering Corporation. Then in 1974 an American consortium - led by Bechtel Engineering, General Electric and Westinghouse - expressed interest in this project as a source of power for uranium enrichment, ushering in a new wave of planning studies centred on a proposed 2160 megawatt dam. While environmentalists in Australia and PNG protested against this scheme (Pardy et al. 1978), it also failed the test of economic feasibility, and was abandoned.

Following a lull in the copra market, in the 1990s, the Papuan Gulf came into focus again as multinational conglomerates began reinvestigating the region's potential for logging and oil production with new technologies. A conjunction of factors in the 1990s - specifically, the increased demand for hardwoods and PNG's fiscal crisis - encouraged both international interest in harvesting these forests and government eagerness to raise revenue by granting concessions (Filer 1997; Filer with Sekhran 1998; Filer et al. 2000). The Purari River constitutes the boundary between two major logging concessions. To the east is the Vailala Block 3 concession (200,100 hectares), which has been controlled by Rimbunan Hijau since 1992 and operational since 1999. To the west is the Baimuru Block 3 concession (438,300 hectares), which was allocated to Turama Forest Industries in 1995, but where logging operations had not yet commenced at the time of writing. ${ }^{10}$

In 2001-02, Rimbunan Hijau subsidiary Frontier Holdings carried out operations in Vailala Block 3 from its original base camp at Kaumeia on the Purari River. The site of this camp is held by the I'ai to be the ancestral site where the female ancestors Keia and Auei paused on their way to find the moon. Over its five years of operation (1999-2004), the camp stripped this site bare, turning it into an eroding patch of earth. The second camp on the Aivei branch of the Purari River near Evara village was opened in 2004. A third camp, simply known as the Purari camp, was opened in 2007 and was still operating in 2012.

This scenario shifted dramatically with the activities of the Canadian company InterOil that began exploratory drilling in the Purari Delta's hinterland in 2002. Despite InterOil's drilling activities remaining spatially remote in 2006, its presence on the upper Purari River continued to loom large in the imaginations of coastal villagers. This was fuelled in part by glimpses of large helicopters carrying equipment inland and by movement of the company's barges up and

10 Permits to Turama Forest Industries (TFI) were first issued in 1988, and in 1995 extended to cover 1.7 million hectares for a duration of 35 years. There were rumours linking TFI to Rimbunan Hijau for many years, but these were only confirmed in 2011, when the Rimbunan Hijau subsidiary Niugini International Corporation Ltd was officially recognised as operator of the Turama concession. 
down the river. As of 2006 InterOil possessed three petroleum prospecting licences (PPL 236, 237 and 238), which covered coastal and inland areas in Central and Gulf provinces. The upper Purari River falls within PPL 238. Since 2009, InterOil's activities have been the source of incredible speculation in the delta communities. In March 2010 I was told of how the company's new base camp being built above the former logging camp at Kaumeia would rival Port Moresby and lift the delta out of obscurity and on to the centre stage of national development. While lobbying for InterOil's proposed overland pipeline to follow the Purari River, community members also talked of an impending meeting to reinitiate the Wabo hydroelectric project on the upper Purari River. In September 2010, the Australian company Origin Energy Ltd and PNG Sustainable Development Program Ltd (PNGSDP) announced a memorandum of understanding to commence the Purari Hydro Scheme (Barrett and Elks 2010). This project was abandoned when the PNG government took over the PNGSDP shares in the Ok Tedi mine in 2012.

\section{The Ebbs and Flows of Violence ${ }^{11}$}

The recent wave of resource extraction and exploration has exacerbated existing tensions in communities and created new problems due to perceptions of unequal royalty payments (Bell 2009). As these projects have unfolded, the state has become increasingly absent. The exception, however, has been the bursts of periodic presence of the mobile squad, who without exception have come to enforce the movement and activities of the logging company. As elsewhere in PNG (Dinnen and Ley 2000; Dinnen 2001; Wood 2006; Lattas 2011), this has distorted people's views of the state and its interests in protecting communities, and helped enforce a growing sense of communities' alienation from their land. To this end, a major campaign promise of the winning candidate in the 2002 Kikori Open election was how, if he was elected, Rimbunan Hijau would fill the void of the state and provide communities with health clinic buildings and roads. Here I recount some aspects of these encounters as they are configured in, and around, a police officer known as Inamu Monovae ('One-Eye').

Violence around the current wave of logging appears to have begun in September 2000 when inhabitants of Aumu village near the mouth of the Aivei River held up a small cargo ship headed to the then-active logging camp of Kaumeia. Due to complications prior to and following the 1997 elections, the I'ai had been at

11 Although presented in a coherent chronological narrative, the events I recount only became clear to me in 2010 with the benefit of hindsight and interviews with community members of Aumu. In October 2000, when I first came to the delta, I had heard about these troubles but until 2010 had not had the chance to interview participants. 
this time frozen out of the project's royalty payments (Bell 2009). Already frustrated by the lack of compensation for the use of their waterways, the men also stopped the vessel because of increased erosion caused by the ships' wakes and the pollution these boats are thought to cause by dumping their bilge. Men took eight pallets of food as payment and then let the ship proceed. A mobile squad from Moresby was dispatched once the incident had been reported and Aumu was raided. I was told how the chief, councillor and teacher were asked to line up and then told to jump into the river and swim to the far bank and back while the police shot the water nearby. Villagers' canoes were riddled with bullets, and all the dogs, ducks and chickens were killed. The terrified villagers ran away and lived in their fishing camps in the forest for a month. They were brought back by the son of a policeman, whom they credit for saving the village from further reprisals. However, for some time, subsequent cargo ships would go by the village at full speed and fire a warning shot or two as they passed. At night these ships would also rake their high-powered spotlights over the village to wake and scare people. Recalling these events in 2010, one man remarked, 'Aumu is the only one fighting for this river!'

This incident was one reason why villagers throughout the Purari Delta were terrified when the mobile squad returned on two separate occasions in 2001 and 2002 (Bell 2006a: 220-1). My return to Baimuru in October 2001 coincided with the arrival of a mobile squad detachment that had not only been dispatched to deal with disturbances at the Kaumeia logging site, but was also raiding villages in a search for illegal home-made firearms and marijuana. The rumours circulating that the police were assaulting women on the coast were such that men in Mapaio talked of how they would meet the police with force if necessary. At the centre of these rumours was One-Eye, a man of Oro and Milne Bay parentage who served during the war in Bougainville. His nickname derives from the patch he wears over an eye damaged in this conflict. Within the delta it is widely believed that One-Eye possesses X-ray vision in this covered eye, which makes him all the more fearsome. More than this, however, narratives also circulated in 2001 and 2002 that, during his persecution of youth in Baimuru, One-Eye berated them in Tok Pisin by saying that his actions were payback because 'your grandfathers ate my grandmothers, now you will eat dirt!'12 When asked about the incident, one elder related how his uncles told him of an event that occurred in Oro Province near Buna during World War II, when they were serving in the Papuan Infantry Battalion and had helped Australian commanders gather and kill Oro men who had collaborated with the Japanese. They were then said to have raped the men's wives and sisters. ${ }^{13}$

12 A, tumbuna bilong yu kaikai tumbuna bilong me, nau yu kaikai graun!

13 I have never been able to ascertain if there is any truth in this remembrance. It may be that the story recalls the Higaturu trials of 1943 during which Papuan collaborators were hanged. 
This man thought that One-Eye was using the police action as a way to enact his own revenge for this historical event and, as his story quickly spread, this only added to local people's fear of the police commander.

In September 2002, One-Eye returned to the delta with a detachment of six men to investigate and retrieve seven chainsaws that had been stolen from the Kaumeia camp. Upon hearing of their imminent arrival in Mapaio, where the I'ai were preparing to host their Independence Day celebrations, the local councillors held an impromptu meeting. Some 30 men gathered in the dark on the village's rugby field to talk about what might happen. The talk that followed revealed their fear of One-Eye and the police more generally, as well as the structural inequalities that logging had brought about in people's access to cash and store-bought goods. The meeting began with one man speaking in the local language: ${ }^{14}$

One-Eye is going to do damage. One-Eye told the workers at Kaumeia base who are holding the chain that he wants to go inside and check if the chain is there or disappeared. While One-Eye went inside to see how far the chain came out from the bush, he wanted to come out and ask the workers questions again. But the workers were frightened and they ran away. They had never seen police. But he did not come to beat them, he just came to check their rooms. The policeman was just asking them, if some say yes they will get pain, but they ran away. When they come to the village it will be a big problem. So these policemen coming will spoil the village. Policemen are saying the village has no trouble in it, but these boys are coming so there will be trouble. The names of the people are in their hands, but if you two councillors are not here they are going to really spoil us ...

One-Eye came down and beat one man at base. That man got all his things and brought out everything in [a] clear place. That is what happened at base. What people did he brought it out. That man was from somewhere else [another area of PNG]. Our small ones were just staying there, and that fellow they belted said everything. Our small ones got frightened and came down. They should have stayed there but they got frightened and came down [to the village].

The speaker and others present urged the councillors to settle the matter before the police came in force and caused the young men to flee into the forest, raising suspicions and most likely leading to their being beaten. One young man was suspected of having fled the camp with a chainsaw and, on hearing of the arrival of the mobile squad, had already fled Mapaio. Another man at the meeting interjected:

You people have not seen the action of One-Eye. I have seen his actions when I went with ... to Epea [Vailala base camp]. He is not going to care about anybody, he will do whatever he wants. One-Eye is not going to care about anyone. He will

14 The following texts have been translated into English with the help of another local man. 
chase the councillors too because the police sent a message for ... who stole [the] company chainsaw for it to be put in the councillor's hands and return it, but you people didn't do it. They have sent [a] message already to do that. But this policeman doesn't care. When he wants to beat people, he will beat them. He will beat the councillors too. This is what I saw in Epea [Vailala].

To this a third speaker added:

The police are coming, we don't know what their thinking is. Some of us don't know how they beat people, some of us go around Moresby and know ... but they are still coming and they are going to be here in the village. So we must think and do the things for the health of the people. Police is coming down, and our children, boys, women and children are going to get pain by running into the bush. They will come and not look to the councillor but hit him and the chief.

As the meeting went on talk whirled about how the villagers had brought this problem on themselves by unduly pressuring their sons and nephews working at Kaumeia to provide them with store-bought food or asking to stay with them while marketing produce at the camp. People also spoke of the evils of kuku dipi and how marijuana was to blame for the stealing of the chainsaws. Invoking more fears of the possibilities of what might happen, a fourth speaker said:

Please if you are father of the house, don't run away because these people are dogs and will do whatever they want. These people are dogs. You don't leave the house if they come in the night, because if you leave the house your wife and daughter will be smashed by them. So just stay in the house, don't leave.

Adding fuel to these fearful speculations, a fifth speaker, a former policeman, remarked on how he had once raided a village in the highlands:

A chopper came up and left us in the middle of the village. When we went to the house there was no one. We burned the house, and just shot the dogs, cats and pigs. They will come down and do this ... they did not sleep good and so they are angry and they are going to come down and do these things. So you young ones must think and do the right things for old ones.

As the night wore on, tensions between men who did and did not have kin working at the logging camp worked themselves out. The councillors urged calm and promised to resolve the matter by finding the stolen chainsaw reportedly located in the village, and that any confrontations would not result in violence. At 2:00 am the group dispersed, still fearful that the night or dawn might bring a raid.

The next day the mobile squad arrived at 9:30 am with One-Eye leading the group. Their arrival caused all sports being played in celebration of Independence Day to stop. Only one young man had fled on the news of their 
arrival. The councillors met with the squad and were given a list of suspects 24 young men who all worked at Kaumeia. While the councillors sat with the Independence Day committee to discuss the names, One-Eye asked me over to talk. Speaking in English, he remarked how he had heard I was here but wasn't sure what I was doing. After I explained my work, One-Eye commented that he was on a routine patrol of the area during which he and his men had confiscated some marijuana up in the border Pawaiian area. He also explained that this operation was about recovering chainsaws, which cost K2,000 each. Two had been recovered but five were still missing. One-Eye then remarked: 'It's for logging - um - because those machines are the ones that are used to make money for landowners. Without those machines the company can't cut logs ... We are coming through the leaders in an easy way.' Then, referring to himself, he noted that 'Papuans are peace loving. Oro Province are like highlanders, they need force.' ${ }^{15}$

Following our brief conversation, One-Eye addressed the villagers assembled on the rugby field in a mixture of Tok Pisin and English:

There are independence celebrations in Gulf, Western Province, Milne Bay, Southern Region too. Oro is where they are strong headed, so when I go [there] I use force like in the highlands. Now we don't come like that this morning. I don't want the community to be scared, so I came to your leaders in a good way. I want you to have a normal Independence Day celebration because plenty of villages have come to celebrate. I want all these people to enjoy PNG independence. So that is why I come in a good way. Now all these people they don't know why the police are come. They have just come to celebrate independence. You have all come to cooperate, which I appreciate. Now you need to work with your leaders. Whatever we do please cooperate with what we need so we can leave you to your celebrations. Because we could have come and raided your village at night but I don't want to do this because you need to celebrate your Independence Day. That is why we came true through to your leaders. Through the leaders we can talk and work with them to find what we need. Force is a last resort, huh? Some places this isn't the case but you people are peaceful. I just want to tell you all this so you can cooperate.

Appealing to purported regional variations in temperament, and playing up what could have happened, One-Eye tried to position himself as a peaceful enforcer of the law. My unconfirmed suspicion was that he had not raided the village in part due to my presence. The chainsaw believed to be in Mapaio was eventually recovered and the young man responsible taken to Baimuru where, in addition to being beaten, he was held in the cargo-holding cell for several days before being released. In the end, the visit was a peaceful one but, as evident

15 My notes are from memory following our conversation. Oro Province is technically part of the Papuan region, but One-Eye seems to have thought of it rather differently. 
in the above commentary, it provoked an outpouring of anxieties about the violence that could come - violence that the men had seen and heard about being inflicted elsewhere. As discussed elsewhere in PNG, these rumours not only create new structures of fear, but they also distort a community's sense of the state, and can significantly reshape what people believe is possible and permissible (Jacka 2001; Kirsch 2002; Butt 2005; Wood 2006). These distortions are constant features of the shifting configurations that are the politics of place and value that resource extraction helps enact (Tsing 2005).

I next encountered One-Eye at the third Rimbunan Hijau logging camp on the Purari River in March 2010. In 11 years since the first camp was established at Kaumeia, logging roads (passable only during the dry season) had connected this site to a logging depot at the mouth of the Vailala River. Moreover, with the economic opportunities present in the logging camp, I had heard how women often visited camps bringing items for sale to workers and their families. Indeed, when visiting the camp, I encountered three Southern Highlands women in the market who were on their third trip down to sell store-bought goods. It was only on my second trip to the camp that I met One-Eye. He saw me and emerged from underneath a house where he was sitting, smoking and speaking with others. After learning what I was up to, and recalling that we had met before, he asked to speak to me out of earshot, and we proceeded to talk for the better part of an hour. He explained how he and some companions had come three weeks ago to establish a police base and how they were conducting periodic patrols. Telling me of his recent patrols to stop marijuana trafficking from Kerema, he also alluded to his membership of a special task force to help ensure law and order in the region, particularly in light of the InterOil project, which he assured me was of special interest to the United States. Earlier in my trip, I had been to the new base that InterOil was building and had met two very bored mobile squad policemen. Armed with automatic weapons like One-Eye himself, it was their job to stop and investigate all river traffic. However, as my I'ai friends explained, their lack of a searchlight meant that it was very easy to slip by the checkpoint under the cover of darkness.

While One-Eye's stature seemed rather diminished by the time we met in 2010 , he was still feared by the I'ai and other Purari communities. His reputation for brutality continued, despite the more limited range of his actions in patrolling the logging roads. But if he and his companions at the InterOil base represented the PNG state, and by extension the companies they ultimately served, their presence was not without friction. As suggested in the next two examples I discuss, narratives abound about how the environment itself is a lively actor pushing back against the actions of these individuals and companies (Tsing 2005: 29). 


\section{Figures of Resistance}

In the late afternoon in March 2010, I sat on the veranda of John's house drinking tea. ${ }^{16}$ My companions and I had come to the settlement of Kae Varia after surveying the upper arm of the Ivo branch of the Purari River from Mapaio. During this trip we had visited the former logging camp at Kaumeia, now green with secondary growth, and had also stopped at the Pawaiian settlement of Poroi before coming down the eastern arm of the Purari. At Poroi we encountered a once-vibrant village reduced to a single household. All the inhabitants had moved up to Wabo to be closer to the activities and possibilities around InterOil's operations there. This trip up the river was an attempt to fulfil a promise I made to the Mapaio community in 2006 to follow up on the survey of the Purari River I had first completed in 2002. Their and my hope was that I would produce a map for the community with ancestral sites and landmarks marked out through a global positioning system. Then and now, communities were deeply concerned about the destruction of ancestral sites by Rimbunan Hijau and now InterOil, and collectively there was a belief that a map could help make their claims legible (Peluso 1995). Indeed, already we had seen evidence of this destruction obliquely through being shown stone tools that workmen had either unearthed themselves or found on the roads as they were being cut.

In 2003, concerned about the direction in which things were headed, John and some 50 men and women had moved to this site on the west bank of the east branch of the Purari River from the Aikavalavi section of Mapaio. I had worked with John's father during my initial fieldwork, and this visit provided us with an important opportunity to catch up after eight years. At the time of my visit his father was convalescing in the regional hospital of Kapuna and died shortly thereafter in 2011. Moving to this spot on the strength of his father's ancestral connections, John and his companions were part of a contingent of I'ai who have moved up the Purari River to have more immediate access to the informal economies of the project areas, as well as to assert their ownership of land that was otherwise not normally inhabited. ${ }^{17}$

16 My return to the Purari Delta in March 2010, after a four-year absence, was shaped by the unexpected death of my adopted father and principle research assistant Kaia Rove. His death was understood to have been connected to ongoing leadership disputes within his clan. 'John' is a pseudonym.

17 At Ne'ea swamp, a traditional fishing and hunting locality, we came upon another group of I'ai from Mapaio who had established a semi-permanent camp on the riverbank in 2006. They had done so to be closer to the Kaumeia logging camp, and to have access to the InterOil project. Prior to their arrival, however, they had been visited by InterOil officials and police telling them that they had a month to vacate the project area or they would be forced to leave. Further down the river is the I'ai village of Vikoiki, an offshoot settlement from Aumu, another I'ai village located further south on the Purari River. Established in 2001, Vikoiki is on the west bank of the Purari River, opposite a now abandoned logging loading point used by Rimbunan Hijau. Indicative of the desires and misunderstandings that the logging and for that matter InterOil's activities are generating, a group of people from Muro (a village site north of Orokolo Bay) has occupied the abandoned logging point since 2008. Their presence and claims to the site have generated a lot of resentment from the residents of Vikoiki who claim the area as theirs. 
The conversation on John's veranda turned to the conditions at the Purari logging camp ten minutes downriver. I had visited the Purari logging camp earlier in the day, spending six hours meeting with workers to ask them about their work conditions. ${ }^{18}$ They were understandably guarded in their conversations with me, and flatly denied that they had any issues with gambling, prostitution, alcohol or marijuana, as documented elsewhere in PNG (Hammar 2010). When I raised this with John and company, the group started laughing and began enumerating the activities that took place in the surrounding area. ${ }^{19}$ John commented how $k u k u$ dipi is the popular one! [Laughing] ... if you were there at night you would find them on the road'. The group said that gambling flourished and that prostitution also occurred. Our talk turned to how the camp had been damaged by fire in March 2009, and the structures I saw had only recently been rebuilt. The only undamaged buildings were the Seventh-day Adventist church and the Asian workers' quarters, which are at some distance from those of the local workers.

By one account of this event, a number of men and some women were gambling, drinking and listening to music in the single men's barracks on the night of the fire. As the revellers carried on, out of the forest and into the building walked a naked white woman. Stunned, the group is said to have watched her walk through and then out of the building. Shortly thereafter the fire broke out and spread wildly. The other story was that someone's small stove had got out of control while boiling water during a late-night gambling session. Men routinely have small kerosene stoves for cooking in their sleeping quarters, where they also hide zoom. Some workers sell stolen fuel on the black market to supplement their marginal incomes, which are all too quickly spent buying overpriced foodstuffs and other consumables in the camp's store. It is thought that the fire accidently ignited a store of this fuel.

While the second story speaks to the grinding conditions of the logging camp, the first story is an example of a particular genre of narrative that I had been hearing since my arrival in the Purari Delta in 2000. These stories focus on how imunu periodically surface and disrupt the activities of the living. The cumulative effects of resource extraction regionally have only further exacerbated the breakdown of people's relations with imunu. Indeed, local people tell of how imunu have either been taken by foreigners, as in the case of one spirit-being that took the form of a stone, or have been driven out by activities like seismic

18 This trip was a follow up on some work I had conducted in the Kaumeia logging camp in 2001 and 2002. On this visit, I interviewed three workers - a grader of roads and two chainsaw operators from Morobe Province.

19 Informal economies flourish both within and alongside these camps due to the captive market of the workers and their isolation. While visiting the next day, we ran into a relative of one of my companions from Iuku village in Orokolo on the coast. The relative had come to the camp to sell betel nut to workers at a huge margin. He remarked how he also sold rum when it was available. 
testing. Large trees are the main home of iri imunu, which makes logging the most disruptive of these activities. In the past, and for those men still conscious of tradition today, protocol dictates that the principal male present addresses the imunu that resides within a large tree before it is cut down to make a house post or canoe. The imunu will be told of the group's intention to cut down their home, and then asked if they will leave. Food is offered to the imunu, and is subsequently consumed by the men. Once the meal is over, the cutting of the tree can commence.

Awareness of these relations within the Baimuru community of Kararua was such that a large feast was held before logging began in their western territories in 1999. During the feast the imunu were asked to find new homes and not to harm the community. The I'ai, with whom I principally worked, never did anything similar, which has made them persistently wary about working at the logging operations and sensitive to the problems that non-placated imunu can cause. As a result, my I'ai friends saw the white woman as the forest manifesting itself and wreaking vengeance on the morally dubious workers. In 2001 and 2002, rumours circulated of how the tutelary ancestral figure Ivia and the stillliving but hidden figure of Tom Kabu were variously behind the endless deluge of rain. The narratives that abounded about these actions directly linked them to local people's exclusion from royalties or compensation payments (Bell 2009).

It was during this trip that I also heard of a kae imunu named Aupea who, in the shape of a stone, blocked InterOil's barges carrying equipment to Wabo. According to my acquaintances, the imunu had, like the white woman, decided that enough was enough, and was actively blocking the barges. His actions were so successful that the barges had to navigate a different river passage to avoid his movements. In these narratives, these imunu become spectral weapons of the weak, disrupting frontier capitalism and opening up spaces through which the I'ai can hope for recognition.

\section{A Scarf Wrapped around the Head}

While the structural violence of resource extraction finds unique expression in the examples I have discussed thus far, it is also found in more quotidian examples. In closing I want to turn to two examples drawn from experiences in Kararua and Mapaio. Separated by eight years, these two examples point to the enduring inequalities engendered by the ongoing resource extraction in the region. 
Just south-west of Baimuru government station, Kararua village is occupied by a confederation of clans that compose the Vaimuru tribe. Regionally, the Vaimuru were the strongest adherents of tradition, but had been receiving timber royalty payments since 2000. This periodic influx of money had increased gambling in the village and was a growing source of domestic strife. This strife took a variety of forms, from kin yelling at one another during the distribution of payments, such as I observed one afternoon, to the inability of the community to come together with contributions of sheet iron to cover one communal building for the sake of an increased water supply. Instead, indicative of their fragmentation, each household had their solitary sheet and catchment. The most profound embodiment of these increased disruptions was in a scarf that an older woman, Kiki, wore tied tightly around her head. I had come to know her husband, Avae, and when visiting Kararua I always made an effort to spend time with them both. On one of my visits, Avae and I began speaking about intergenerational problems caused by logging. Our talk quickly turned to gambling, and then to Kiki's scarf. Avae and Kiki disclosed how her scarf kept a skull fracture in place, and how Kiki was racked with headaches without it. One day, as they gambled with newly dispersed royalty payments, one of their sons ran out of funds. On being refused a loan by his mother, he hit her with a wooden plank. The family had since mended the social strain that this violence had caused, but Kiki continued to suffer the legacy of this encounter. Avae's anger had not abated, and he had all but concluded that he would die keeping all his knowledge of his descent group's lands to himself.

In 2010, when I returned to Mapaio, I found that gambling also dominated life in the village, yet people were even more outspoken about the pollution of the Purari River. This is the main source of drinking water for the community, and a major source of food (fish, crayfish, etc.) and water used in the processing of food (sago). For years community members had noticed that sedimentation in the water had increased, the taste had deteriorated, and there were more ailments associated with unpalatable water, such as intestinal complaints and more frequent and lasting sores. Indeed, eye infections and body sores, which were previously confined to the wet season, were now a constant occurrence. One small girl's sore was so bad that her toe had to be removed. Alongside these health issues, fish were increasingly found covered in sores.

One possibility is that these sores may be due to the effects of increased population in the central highland provinces. In his discussion of aquatic pollution discerned from testing in 1978, Petr (1983: 329) notes that the Purari catchment receives wastewater from the major towns of Goroka, Kundiawa, Minj, Mt Hagen and Mendi. Increased faecal material from the greater animal and human populations in the catchment could be increasing these various health and environmental problems. However, Petr notes that the Purari River 
at Wabo appears to be self-purifying and, in any case, pollution of the main river should not be such a great concern because 'people along the Purari prefer drinking rainwater and water from side streams' (ibid.: 331). While this preference still exists, the reality is that many communities do not have an alternative to drinking the water from the main river.

It is also likely that the higher sedimentation load is caused by deforestation both in the delta and in the highlands. While it remains to be seen whether InterOil's activities are having the sort of effects on the Purari River that are experienced by the community of Mapaio, the company's community affairs officers have warned communities against drinking the river water or eating dead fish found in the river. They did not link these restrictions to the company's own activities, but one cannot help but speculate on the relationship.

\section{Conclusion}

If place-making is a way of constructing the past, a venerable means of doing human history, it is also a way of constructing social traditions and, in the process, personal and social identities. We are, in a sense, the place-worlds we imagine. (Basso 1996: 7)

In this chapter, I have attempted to think through the place-worlds that resource extraction in the Purari Delta helps to imagine, and with it think through the structural violence these activities give rise to and help enact. Working in this region, one is very aware of the legacy of earlier representations, how writers seeking to bracket and frame the Purari people portrayed them as primordial cannibalistic semi-aquatic mud dwellers (Bevan 1890: 186-8; Murray 1912: 197; Holmes 1924: 28-9). While the violence of these representations is only obliquely felt locally (Peluso 2003), spectres of this past do periodically appear. I have tried to expose aspects of the micro-politics of structural violence in the Purari Delta, show how resource extraction structures life at the cost of local communities, how companies use police forces to make communities comply with their wishes, and how communities themselves become more violent in the wake of the new instabilities of wealth and power that resource extraction brings (Lattas 2011). In doing so, I hope not to paint too bleak a picture of the Purari Delta where, despite the problems I outline, people find the resilience to joke, laugh, sing and enjoy aspects of their lives. However, the situation in the delta, as in other regions affected by such projects, is stark and not to be understated (Kirsch 2006; see other contributors to this volume). My hope is that in bringing together these histories, and contemporary accounts, more attention 
will be brought to bear on the impacts of resource extraction regionally, and that the affected communities may begin to obtain the justice they deserve and the compensation they need.

When I asked a long-term friend and Mapaio resident, Henry, about the way he saw the future for his children in light of these events in 2012, he remarked:

Like I have said, myself I am not going to stop [it] because the people they want the development to go in. The government wants the development to go in. If I a village person goes to stop the development then the government is going to come against me and beat me again. So that is why the village they want to stop the particular project for the future but the government is forcing that thing to happen. So we have no power to stop it. We have concern for our children there to stop it but we have no power because the government has power to do everything there. So our government is not concerned about histories they are just going in and doing these things inside.

\section{References}

Agrawal, A., 2005. Environmentality: Technologies of Government and the Making of Subjects. Durham (NC): Duke University Press.

Barrett, R. and S. Elks, 2010. 'Papua New Guinea River to Power Up North.' The Australian, 16 September.

Basso, K. 1996. Wisdom Sits in Places: Landscape and Language among the Western Apache. Albuquerque: University of New Mexico Press.

Bell, J.A., 2006a. 'Marijuana, Guns, Crocodiles and Radios: Economies of Desire in the Purari Delta.' Oceania 76(3): 220-34.

Bell, J.A., 2006b. 'Losing the Forest but Not the Stories in the Trees: Contemporary Understandings of the Government Anthropologist F.E. Williams' 1922 Photographs of the Purari Delta, Papua New Guinea.' Journal of Pacific History 76(3): 191-206.

Bell, J.A., 2009. 'Documenting Discontent: Struggles for Recognition in the Purari Delta of Papua New Guinea.' The Australian Journal of Anthropology 20(1): 28-47.

Bell, J.A., 2010. 'Out of the Mouths of Crocodiles: Eliciting Histories with Photographs and String Figures.' History and Anthropology 21(4): 351-73. 
Bell, J.A., 2013. " "Expressions of Kindly Feeling": The London Missionary Society Collections from the Papuan Gulf.' In L. Bolton, N. Thomas, L. Bonshek and J. Adams (eds), Melanesia: Art and Encounter. London: British Museum Press.

Bennett, J.A., 2009. Native and Exotics: World War II and Environment in the Southern Pacific. Honolulu: University of Hawai'i Press.

Bevan, T.F., 1890. Toil, Travel, and Discovery in British New Guinea. London: K. Paul, Trench, Trubner.

Bourdieu, P., 1991. Language \& Symbolic Power (ed. J.B. Thompson, transl. G. Raymond and M. Adamson). Cambridge (MA): Harvard University Press.

Brunois, F., 1999. " "In Paradise, the Forest is Open and Covered in Flowers." ' In C. Kocher Schmid (ed.), Expecting the Day of Wrath: Versions of the Millennium in Papua New Guinea. Boroko: National Research Institute (Monograph 36).

Butt, L., 2005. " "Lipstick Girls" and "Fallen Women": AIDS and Conspiratorial Thinking in Papua, Indonesia.' Cultural Anthropology 20(3): 412-42.

Carne, J.E., 1913. 'Notes on the Occurrence of Coal, Petroleum, and Copper in Papua.' Melbourne: Department of External Affairs (Bulletin of the Territory of Papua 1).

Chance, S.H., 1937. 'Kikori Patrol Report No. 8 of 1936/37, 10-22 March 1937.'

CWM/LMS (Church of World Mission/London Missionary Society), 1913. 'Papua Letters, Box 14, Folder 1, Jacket B, 18 April 1913 (GB0102).' London: School of Oriental and African Studies Library.

Dinnen, S., 2001. Law and Order in a Weak State: Crime and Politics in Papua New Guinea. Honolulu: University of Hawai'i Press.

Dinnen, S. and A. Ley (eds), 2000. Reflections on Violence in Melanesia. Canberra: Asia Pacific Press.

Farmer, P., 2004. 'An Anthropology of Structural Violence.' Current Anthropology 45(3): 305-25.

Filer, C. (ed.), 1997. The Political Economy of Forest Management in Papua New Guinea. Boroko: National Research Institute. London: International Institute for Environment and Development. 
Filer, C. with N. Sekhran, 1998. Loggers, Donors and Resource Owners. London: International Institute for Environment and Development in association with the PNG National Research Institute.

Filer, C. with N.K. Dubash and K. Kalit, 2000. The Thin Green Line: World Bank Leverage and Forest Policy Reform in Papua New Guinea. Canberra: The Australian National University, Research School of Pacific and Asian Studies.

Galtung, J., 1969. 'Violence, Peace, and Peace Research.' Journal of Peace Research 6(3): 167-91.

Gordillo, G., 2011. 'Ships Stranded in the Forest: Debris of Progress on a Phantom River.' Current Anthropology 52(2): 141-67.

Hammar, L., 2010. Sin, Sex and Stigma: Pacific Response to HIV and AIDS. Wantage (UK): Sean Kingston.

Harvey, D., 2005. The New Imperialism. Oxford: Oxford University Press.

Hicks, E.G., 1953. 'The Search for Petroleum in the Territories of Papua and New Guinea.' South Pacific 7: 688-700.

Holmes, J.H.R., 1924. In Primitive New Guinea. London: Seeley, Service \& Co.

Hope, P., 1979. Long Ago Is Far Away: Accounts of the Early Exploration and Settlement of the Papuan Gulf Area. Canberra: Australian National University Press.

Jacka, J., 2001. 'Coca-Cola and Kolo: Land, Ancestors and Development.' Anthropology Today 17(4): 3-8.

Karius, C.H., 1937. 'Kikori Patrol Report No. 7 of 1937/38, 8-11 December 1937.'

Kirsch, S., 2002. 'Rumour and Other Narratives of Political Violence in West Papua.' Critique of Anthropology 22(1): 53-79.

Kirsch, S., 2006. Reverse Anthropology: Indigenous Analysis of Social and Environmental Relations in New Guinea. Stanford (CA): Stanford University Press.

Kosek, J., 2006. Understories: The Political Life of Forests in Northern New Mexico. Durham (NC): Duke University Press.

Lattas, A., 2011. 'Logging, Violence and Pleasure: Neoliberalism, Civil Society and Corporate Governance in West New Britain.' Oceania 81(1): 88-107. 
Leach, J., 2004. 'Land, Trees and History: Disputes Involving Boundaries and Identities in the Context of Development.' In L. Kalinoe and J. Leach (eds), Rationales of Ownership: Transactions and Claims to Ownership in Contemporary Papua New Guinea. Wantage (UK): Sean Kingston.

Lewis, D.C., 1996. The Plantation Dream: Developing British New Guinea and Papua, 1884-1942. Canberra: Journal of Pacific History.

Liston-Blyth, A., 1925. 'Kikori Patrol Report No. 1 of 1925/26, 2-5 August 1925.'

LMS (London Missionary Society), 1906. Reports of the London Missionary Society, No. 111: From April 1st, 1905 to March 31st, 1906. London: Alexander \& Shepheard.

LMS (London Missionary Society), 1915. Reports of the London Missionary Society, No. 120: From April 1st, 1914 to March 31st, 1915. London: Alexander \& Shepheard.

Maher, R.F., 1961. New Men of Papua: A Study in Culture Change. Madison: University of Wisconsin Press.

Maher, R.F., 1984. 'The Purari River Delta Societies, Papua New Guinea, after the Tommy Kabu Movement.' Ethnology 23(3): 217-27.

Murray, J.H.P., 1912. Papua or British New Guinea. London: T. Fisher Unwin.

Nicklason, N., 1969. 'The History of Steamships Trading Company Limited.' In K.S. Inglis (ed.), The History of Melanesia. Port Moresby: University of Papua New Guinea. Canberra: The Australian National University, Research School of Pacific Studies.

Pardy, R. et al., 1978. Purari Overpowering PNG? Fitzroy (Melbourne): International Development Action for Purari Action Group.

Peluso, N.L., 1995. 'Whose Woods Are These? Counter-Mapping Forest Territories in Kalimantan, Indonesia.' Antipode 27(4): 383-406.

Peluso, N.L., 2003. 'Weapons of the Wild: Strategic Uses of Violence and Wildness in the Rain Forests of Indonesian Borneo.' In C. Slater (ed.), In Search of the Rain Forest. Durham (NC): Duke University Press.

Petr, T., 1983. 'Aquatic Pollution in the Purari Basin.' In T. Petr (ed.), The Purari: Tropical Environment of a High Rainfall River Basin. The Hague: Dr W. Junk.

Pym, L.A., 1958. 'Oil Exploration in Papua: Transport Problems.' Walkabout 24(2): 10-14. 
Raffles, H., 2002. In Amazonia: A Natural History. Princeton (NJ): Princeton University Press.

Rickwood, F., 1992. The Kutubu Discovery: Papua New Guinea, Its People, the Country and the Exploration and Discovery of Oil. Glenroy (Australia): Frank Rickwood.

Ross, J.C., 1943. 'Kikori Patrol Report No. 2 of 1943/44, 9-20 August 1943.'

Ryan, H.J., 1914. 'Kikori Patrol Report No. 16 of 1914/15, 24 November 8 December 1914.'

Scheper-Hughes, N. and P. Bourgois, 2004. 'Introduction: Making Sense of Violence.' In N. Scheper-Hughes and P. Bourgois (eds), Violence in War and Peace: An Anthology. London: Blackwell.

Territory of Papua, 1923. Annual Report for the Year 1921-22. Government of the Commonwealth of Australia.

Tsing, A.L., 2005. Friction: An Ethnography of Global Connection. Princeton (NJ): Princeton University Press.

Wade, A., 1914. Petroleum in Papua. Melbourne: Government Printer for State of Victoria.

Wagner, R., 1981. The Invention of Culture. Chicago: University of Chicago Press.

Welsch, R.L., V.L. Webb and S. Haraha, 2006. Coaxing the Spirits to Dance: Art and Society in the Papuan Gulf of New Guinea. Hanover (NH): Hood Museum of Art and Dartmouth College.

Williams, F.E., 1923a. 'The Pairama Ceremony in the Purari Delta, Papua.' Journal of the Royal Anthropological Institute of Great Britain and Ireland 53: 361-87.

Williams, F.E., 1923b. The Vailala Madness and the Destruction of Native Ceremonies in Gulf Division. Port Moresby: Government Printer.

Williams, F.E., 1924. The Natives of the Purari Delta. Port Moresby: Government Printer.

Wood, M., 2006. 'Kamula Accounts of Rambo and the State of PNG.' Oceania 76(1): 61-82.

Woodward, R.A., 1921. 'Kikori Patrol Report No. 2 of 1921/22, 21 July 4 August 1921.'

Woodward, R.A., 1922. 'Kikori Patrol Report No. 7 of 1922/23, 23-31 October 1922.' 
This text is taken from Tropical Forests of Oceania: Anthropological Perspectives, edited by Joshua A. Bell, Paige West and Colin Filer, published 2015 by ANU Press, The Australian National University, Canberra, Australia. 